\title{
Survey of Love and Marriage in Janette Oke's Fictions
}

\author{
Sayyed Ali Mirenayat ${ }^{\star}$, Elaheh Soofastaei \\ Faculty of Modern Languages and Communication, Universiti Putra Malaysia \\ `E-mail address: ali.mirenayat@yahoo.com, ela.soofastaei@yahoo.com
}

\begin{abstract}
Love is a responsibility in being fond of others that is higher than a desire of friendship, for sure. It is something more than overcoming our loneliness, though human needs a power to escape from his loneliness. As a social being, human requires others to live, especially in opposite sex. In Janette Oke's novels, the nature and meaning of love is the common path in choosing a life partner for marriage. In her view, marital love is a main principle in transcending human life. In her novels, when pure love happens in which we love somebody honestly without expecting reciprocation. In such relationship, the lover can only adjust his behaviors to show the message of love. Oke tries to show that the romantic love is the basis of the most extreme pleasure that our life needs.
\end{abstract}

Keywords: Love; Marriage; Family; Relationship; Friendship

\section{INTRODUCTION}

Love has always been one of the most popular themes in English literature. In recent decades love, marriage and family have become particularly struggled issue in Canada and even throughout most western countries. Faith and love have become separated, to a great extent. Janette Oke as the Canadian pioneer of Inspirational Fiction has written many novels based on love, faith, and Christianity. Her novels' settings are $19^{\text {th }}$ century and she tries to show pure love through the presence of faith between the couples. Family is a rendezvous in where Oke's characters usually meet their personal needs and wishes. Women care for men, but are dependents on their men's financial supports. Men, as well, love women and it seems that only death can separate them from each other. Love, in her fictions, cannot be concealed - like a flame that it makes its presence felt, either by the glimmering light or at least by its smoke. In particular, it is approximately impossible to assume how passion in the self-renunciation sense of one's character and definite yielding to marriage is assumed to be performed. Such stories are harmonized with the role of love and faith in people's life.

Therefore, fall in love means to internalize another one's individuality systematized opinion of the universe. Love gets its name from the word for hook, which means "to capture" or "to be captured," for lover who is in love is captured in the prison of desire and wishes to capture somebody else with his hook (Chaucer and the English Tradition 22). Like a skillful fisherman who attempts to allure fish by his bait to capture them on his hook, so the man who is prisoner of 
love attempts to allure the beloved by his attractions and makes all his efforts to unify two different hearts with impalpable bond.

The initial meaning of love is from Persian poetry in origin. Love is not a problem to answer a question. There is a very close relationship between peace and love, whereas if there is no peace, there is no light (love). Thomas Merton believes when we speak about falling in love, we should imagine it like water in puddles, pools, lakes, rivers, and seas. You can fall into it or walk around it. You can sail on it or swim in it, or you can just look at it from a safe distance (Love and Living 25). The concept of love in each case gives a comprehension of the relationship between symbolic media and social frame. As for medium of love, it is positioned in the reality that communication is very personalized which is taken to mean that one tries to begin with another person.

Love influences more than our thought and conducts to whom we love. It changes our whole life. True love is an individual revolution. It takes our ideas, wishes, and our behaviors to attach them together in one different experience and one reality of life which is new life for us. In Oke's novels, love is considered as a deal which presumes that we all have requirements which have to be done by changing. But it is not a deal, but also it is a funny bit of fortune that happens when you end up with another one whose require the same requirement more or less than what you have. Love is a void and hollowness that can be utilized. It is a kind of idolizing in which there is a sacrificial offering. It is a superior spiritual power which is known as the most profound inventive power in human nature. It is gratitude of life as value and priceless gift. It has its own sagacity and its way to explore the internal deepness of life in the secrecy of the beloved. Person in love knows, understands, and meets all needs of his life insofar as love answers with warmth and friendliness. When people are honestly in love, they can get experience a reciprocal need for their beloveds and friendship.

Love is the reason of all good narcissism, tidiness, plays, tenderness, pleasure, delightful utterances, and pleasant actions in our life. If two stranger persons suddenly let the emotional barrier break down in between and feel closer than before, so this moment of unity is one of the most delightful experiences in life. Love is the only teacher that human will require, though many people do not comprehend it. Through love, human will find out how to treat others in the world. Oke attempts to show that if everyone acts from the perspective of love, all destructive things would not occur. In her view, love means doing what is right, not having sexual feeling to the opposite sex. It also means looking at ourselves with a critical and forgiving eye to change things which are not needed.

The generality of marriage does not mean that everybody in every society gets married. It means only that most people in everywhere get married at least once in their life time. Marriage and family, the two social institutions with biological basis, are harmonious to each other. Marriage is one of the social foundations in the world. It is set up by the human society to manage and adjust the sex life of human being. Marriage only means a socially accepted sexual and economic unity between a man and a woman; that is the lawful unity of male and female.

\section{NATURE OF LOVE}

Janette Oke in one of her novels Love Comes Softly, shows that love is a changing strength of spiritual power which endows the lovers with circumstances and capabilities they never 
thought and they could own. In this novel, love is not only a specific way of being alive, but also it is the improvement of life. The lover is more alive and perfect than before. The strength of his love is as strong as a mountain that it cannot be deviated from its goal. This is natural, to some extent, because when we fall in love, our sense of love can make different our thoughts, though our incorrect thoughts can prevent love. Sir Walter Raleigh says "love is a tooth-ache or like pain, it is a game where none doth gain" (the Monthly Mirror 232).

In this novel, loneliness is one the major problems which the male characters have. As an unbearable problem, men are not able to leave it easily and they are always struggling with it. They need an energetic supplement to flee from their restless jail of isolation. Without love, they could not exist for a long time. Self-love is a strong feeling of respect for confidence in oneself which Oke has used in this novel. It is completely different from narcissism and it is a selfacceptance, in fact. But we should not misunderstand it with self-interest. As Joseph Butler says "self-love does not constitute this or that to be our interest or good; but our interest or good being constituted by nature and supposed, self-love only puts us upon obtaining and securing it" ( SelfInterest 123).

In most of her novels, a relationship between love and society is available. They show that human as a social creature requires the existence of others to be social, communicate, and to remain alive. She proposes friendship as one the best ways in which humans fill their hollowness with the others in society, and love is the deepest level of this social behavior. What is being scrutinized is a social phenomenon in societies called nature of love which is a special structure for choosing a life partner to lead in marriage. But in nowadays' societies, marital love is replaced with white marriage which has not enough mutual foundation as marriage owns.

Oke defines love as a moral emotion in society. To her, love and morality are mainly presumed to be different in spirit. The moral viewpoint is unbiased and it supports no specific person. She believes that if humans find themselves separating from love and morality to keep the peace, they have already gone a wrong way. So, love is a moral emotion in the sense which its spirit is nearly related to morality. When we say that love is a moral emotion in society, it means that what we have in mind is the love between close friends and our life partner.

\section{TRIANGULAR THEORY OF LOVE}

In nineteenth century, there had been paradoxicalization of the concept of love in society. In another two Oke's novels Love's Abiding Joy and Unending Legacy, the unity of love marriage and marital love is available. In the setting of these two novels, reader can understand that the lovers' dialogues are related to the cultural and historical background of the stories. We evidently can see it in most of her novels. Love is no longer depended on a display of physical and moral characteristics. Families from the upper social class have lost their nobility, but love plays a significant role to keep the house environment peaceful. We can see that bilateral dependency reinforces enduring love. Oke's fictional characters have the balance of dependency.

Literature on the subject of love and friendship in nineteenth century emphasizes that people who are looking for their destiny and fortune. One, for example, is a person in so far as it was of little or no result in socially intimacy relationships whether one was from a middle class person or a very rich family.

In Love Finds a Home and Love's Unfolding Dream, we cannot see an overabundance of passion because it is a bar to love. There are men who are slaves of their sexual desire and they cannot be held in the chains of love. This is the main feature of our present century in the West which is not seen in Oke's novels. And also there are men who think about some women and 
even sleep with them, but when they see another one, they forget every moment that they have spent with their former persons. This is what is happening around us at the present time. But a contemporary writer like Oke tries to remember us our ancestors' past and the treatment of love.

According to Robert Sternberg, every love relationship falls somewhere within the triangle of commitment, intimacy, and passion. He believes that human's experience of love depend on the strength or weakness of each of those elements. He says these three items are so important in having love in society. This is the fact in Oke's fictions and she has created an area in the middle of this triangle called consummate love which was coined by Sternberg (The Psychology of Love 231).

\section{CONCLUSION}

The lovers, in Janette Oke's novels, are not aggressive and ambitious. They are social and tolerant. Love is mostly a spontaneous personal experience which then might result in marriage. They are not contacted by agreement and the related families, or marriage dealers, or without the help of such mediators such as what was in nineteenth century. Philosophy, religion and art in her works have portrayed love in its position as a method to a higher level of being very beautiful. In her works, women expected to marry and have children and there were unconditional forms of marriage. They romanticized love and caring for as female features that recompensed for men's powers and economic situations. Men also romanticized women as freely giving these training services and feelings rather than exchanging gifts for security, food, and shelter for wife and their children.

\section{References}

[1] Robinson, Ian, Chaucer and the English Tradition. CUP Archives (1975) 17-37.

[2] Merton, Thomas, Love and Living. Macmillan (2002) 18-40.

[3] Smith, Charlotte, the Monthly Mirror. London (1970) 232-233.

[4] Rogers Kelly, Self-Interest: An Anthology of Philosophical Perspectives from Antiquity to the Present. Routledge (1997) 123-124.

[5] Sternberg, Robert J., the Psychology of Love. Yale University Press, 1988.

[6] Capellanus, Andreas, the Art of Courtly Love. New York: Columbia UP, 1990.

[7] De Rougemont, Denis. Love in the Western World. Princeton UP, 1983.

[8] Fromm, Eric. The Art of Loving. New York, 2000. Harper \& Row, 1956.

[9] Mirenayat, Sayyed Ali. The Treatment of Love in Janette Oke's Selected Novel. MA Diss, 2012. 